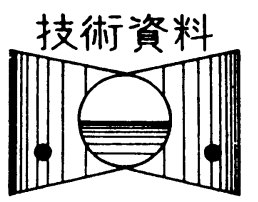

\title{
練習船“弓削丸” のプロペラ塗装実験*
}

\author{
小川 量 也** ・松下 邦 幸**
}

Propeller-coating of Training Ship "YUGE-MARU”

By Kazuya Ogawa and Kuniyuki Matsushita

Many kinds of sea livings accrete to the propeller surface of ships at anchor. As a result, main engine gets into the torque-rich condition and the rotational frequency of propeller decreases. These cause the drop of propulsion efficiency.

To prevent the accretion of sea livings, propeller-coating has recently been examined by using anti-fouling and self-polishing type paint which contains copper compounds and organic tin compounds. This type of paint is much used now for the bottom plates of ships or fishing nets for ocean cultivation etc.

It becomes, however, one of the severe social problems since our sea environments is polluted by the toxic components or heavy metal of the paint dissolving out into the sea.

Then, the experiments wrer made applying propeller-coating to our training ship "YUGE-MARU" by using a nontoxic paint which is made of special silicon resin and which is fit for special uses at land.

The results of one year's experiment show that the surface of propeller is kept clean and the film of painting is attached firmly to the surface.

By these effects of this coating, the corrosion protection of ship has been improved and the amount of fuel consumption of main engine has been reduced $6 \%$.

\section{1.まえがき}

鋼船の船体外板は, 海水による腐食から鋼板を保護す るために防食塗装が施されているが, 種々の外的要因に より船体は損傷を受けやすく，塗膜が剝離することがあ るので, 塗装だけでは船体の防食は完全であるとは言え ない，そこで，このような塗膜の欠陥を補い，防食効果 を高めるために電気防食が併用されている。

電気防食としては, 外部電源法や流電陽極法 ${ }^{1)}$ が一般 に用いられているが, 後者は, 電源を必要としないこ と, 施工が簡単で保守が容易なこと, 維持費が不要であ ること,などの利点があるため, 多くの船に用いられて きた。本校練習船 “弓削丸”る本防食法を採用してい る. 図 1 に船体の概観と儀牲陽極の配置を示す. 儀牲陽 極としては覀鉛板を使用している.

特に, 船尾には銅合金製のプロペラが存在するため, このプロペラと鋼製の船体との間で起こる電気化学的作

*原稿受付 平成 2 年 2 月 2 日

平成元年秋期学術講演（平成 1 年 10 月 18 日)

**正会員 弓削商船高等専門学校 (受媛県越智郡弓削町下 弓削1000)

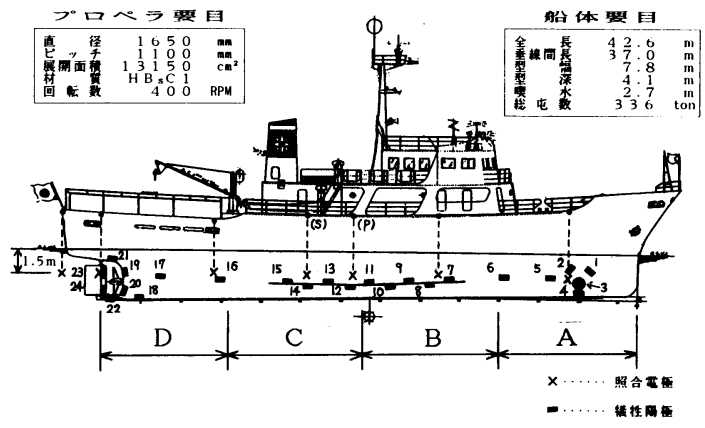

図 1 船体電位計測時の照合電極位置及び犠牲陽極 （亜鈶板）の船体取付位置

用による腐食も大きくなるので，その近傍には多数の儀 牲陽極が配直してある。

しかし，この儀牲陽極の個数が多すぎると，船体抵抗 が増大するばかりでなく，船体は過防食に宿り，塗膜が 劣化する恐れがある.また，プロペラは船体や锇牲陽極 によって院極防食されるため銅イオンの溶出が押さえら れ, 海中生物の付着による污損が増大し, 推進効率の著 しい低下を招くことになる．本船の場合も，このような 弊害が㗭念される. 
そこで，筆者らは，その防止対策としてプロペラ塗装 を計画し，かねてより，各種の市販塗料を使用した実験 を行ってきた. プロペラ塗装を行らと，銅表面と海水と の接触が断たれ，上記の電気化学的腐食が抑制されるの で，船体に設置される儀牲陽極の個数は少なくてすむ． さらに，このプロペラ塗装に防污用銼料を使用した場合 には，翼面への生物の付着が一段と阻止できるため，前 述の推進性能面に沶いても効果があるものと思われる.

そこで筆者らが着目した塗料は，某塗料メーカーのシ リコン系特殊合成樹脂塗料である。この鉒料は, 現在, 原子力発電所の取水口や復水器循環水管などの防污用と して使用されているもので, 従来の防污塗料とは違っ て，塗膜自体の物理的性質を利用したものである。すな わち，塗膜表面は低臨界表面張力を有するため，接触角 が大きく（図 2)，液体をはじく性質を有しているので， 海中生物が体内から出す接着性のセメントが塗膜面に付 着しないか，あるいは付着力が弱められるというもので ある2).

現在，船舶や養殖漁絧などに多量に使用されている防 污塗料には，亜酸化銅や有機錫化合物などが防污剤とし て含有されているが，これら有害な物質が長年に渡って 海中に広く溶け出し，海水が污染されてきているので， 大きな社会問題になっている，本シリコン系塗料はこの ような心配の全くない無害な塗料である゙2.

本報は，著者らがこれまで行ってきた塗装実験 ${ }^{3 / \sim 5)}$ ， すなわち，試験板による浸漬実験及び実船を使用したプ ロペラ塗装実験の結果を集約し, 塗料の防污性・塗膜の 密着性の観点から，本染料がプロペラ用塗料として適用

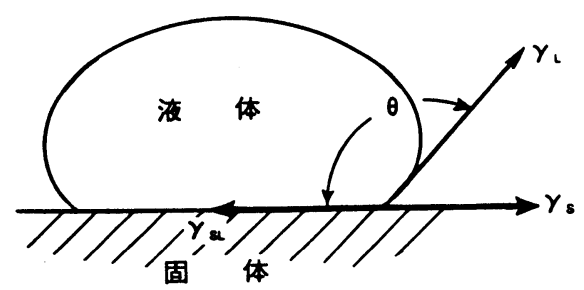

$$
\begin{aligned}
\gamma_{\mathrm{SL}} & =\gamma_{\mathrm{S}}-\gamma_{\mathrm{L}} \cos \theta \\
& \\
r_{\mathrm{s}} & : \text { : 固体の表面張力 } \\
r_{\mathrm{L}} & : \text { 液体の表面張力 } \\
r_{\mathrm{SL}} & : \text { 固体 } / \text { 液体間の界面張力 } \\
\theta & : \text { 接触角 }
\end{aligned}
$$

$\theta$ が大きいほど固体表面はぬれにくく， 付着しないではしくようになる.

図 2 固体と液体との接触
可能かどうかを検討したものである．浸漬実験は本校の 学校栈橋を利用し，実船実験は本校練習船 “弓削丸”を 使用した。また，短期間ではあるが，FRP船を使用した 船体塗装実験も試みた。

\section{2.基礎浸清実験}

船体やプロペラなどに付着する海中生物の種類や付着 状況を把握するために, $40 \times 25 \times 0.3 \mathrm{~cm}$ の単独試験板と 租合せ試験板を水面下約 $2 \mathrm{~m}$ の位置に吊り下げ，定期的 な観察を行った。

単独試験板は，プロペラからの溶出銅イオンの付着生 物に及ぼす影響を見るために，無塗装でかつ中央に儀牲 陽極（亜鉛）を取り付けた防食黄銅板と，無㳂装で儀牲 陽極のない非防食黄銅板の 2 種類準備した。

組合せ試験板は，船体とプロペラとが接続された状態 を想定して軟鋼板と黄銅板を電気的に短絡したものであ る.軟鋼板はいずれも塗装がなされており，黄銅板は無 塗装とシリコン系特殊合成樹脂塗装の 2 種類である.

なお，本練習船のプロペラ材質は第 1 種高力黄銅鋳物 であるが，入手が困難なため，試験板としては市販の黄 銅板 $(\mathrm{Cu}: 59.9 \%, \mathrm{Zn}: 40 \%, \mathrm{~Pb}, \mathrm{Fe}$ 極少含有) で代用 した.

塗装は，“弓削丸”での実船実験の場合と同様の手順 で行った．その塗装要領を表 1 に示す.

な拉, 当実験場所に和ける潮流の速度は $0 \sim 2 \mathrm{knot}$ の 範囲で変化し，1 日 2 回その向きを変える. 海水の温度 ・溶存酸素量などは後揭の図10中に記してある.

図 $3 \sim$ 図 5 は，3月浸漬開始後 $6 \sim 8$ ケ月経過後の各 試験板の污損状態を示す．海中生物の種類・成育期は海 水温度, 溶存酸素量, 流速など海水環境によって異なる $か^{6), 7)}$, 本実験場所に括いて比較的成長が著しい 9 月また は11月の写真を代表として掲げ，各試験板について污損

\begin{tabular}{|c|c|c|c|c|}
\hline & & 作 㨀 手 順 & 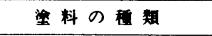 & 槽 \\
\hline \multirow{3}{*}{ 船 } & 1 & 下地処理 & $\begin{array}{l}\text { (プラストクリーニンクク) } \\
\text { (エアークリーニンク) }\end{array}$ & 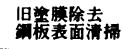 \\
\hline & 2 & $\begin{array}{l}\text { 下地望装 } \\
\text { (ショッフライマー) }\end{array}$ & エポキシ媩脂柔 & 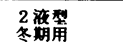 \\
\hline & 3 & 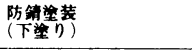 & タールエポキシ澍脂 & 2 回塑り \\
\hline \multirow[t]{2}{*}{ 体 } & 4 & 中関辡 & ビニール樹脂 & \\
\hline & 5 & $\begin{array}{l}\text { 防活等 } \\
(\text { 上装り) }\end{array}$ & 自己研掅型長期防污 & $\begin{array}{l}2 \text { 回辡 } \\
\text { 有機含有 }\end{array}$ \\
\hline \multirow{3}{*}{$\begin{array}{l}\text { フ } \\
\text { 口 } \\
\text { ○ } \\
\text { ラ }\end{array}$} & 1 & 下地処理 & 研㢞 & \\
\hline & 2 & 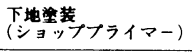 & (バインター添加獄掍入) & $\begin{array}{l}\text { ハタ辡り } \\
\text { (3.も同し) }\end{array}$ \\
\hline & 3 & $\begin{array}{l}\text { 防污湆装 } \\
(\text { 上㙬り) }\end{array}$ & シリコン柔特珠合成㙁脂 & 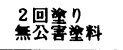 \\
\hline
\end{tabular}
状況を概説する。

2.1 単独黄銅板（無塗装・非防食）の結果（図 3）浸漬後から黄銅板表面は海水腐食により, 次

表 1 弓削丸の船体・プロペラ塗装要領 (S63. 3 H1.3) 
第に粗面を呈してきた．３ケ月後には，至るところに白 色の析出物が見られたが，この物質は亜鉛と海水成分と の化合物（炭酸塩）ではないかと推定している。

全浸漬期間を通して, 生物の付着は全く観察されな かった。これは, 黄銅中の銅イオンの溶出による付着・ 成長阻止効果と考えられる。

2.2 単独試験板（無塗装・防食）の結果（図 4) 本試験板は, 中央に円形の亜鉛板を取り付け て黄銅板を電気防食したものである。図 3 の非防食板と は大きく様相が異なっている，すなわち，非防食板の場 合には生物の付着が全く見られなかったのに対して，本 防食板の場合には，浸漬３ケ月目（6月）に群体ホヤが 成長，フサコケムシもすでに $20 \%$ 程度付着・成長して拉 り，4 ケ月目（7月）にはその付着率が $40 \%$ 以上にも達 した，以後は衰退に向かったが，代わってチゴケムシが 9 月にかけて繁殖した。その後, フジッボ類・カンザシ ゴカイ類・ホヤ類などが多数付着してきた。

本試験板へのこのよらな多量の生物の付着は, 非防食 板とは違って，卑金属である亜鉛によって完全に防食さ れ，生物にとって害のある銅イオンの溶出が押えられた ためであると考劣らる。このことについては，三原氏 の文献中にも述べられている

\section{3 軟鋼板（塗装）－黄銅板（無塗装）の結果}

（図 5 A）浸漬後まもなく，軟鋼板の四隅の取付 け孔周辺が急激に発錆し，1 万月後には試験板が吊り下 げロープから脱落する恐れがあったので，急遽内側に孔 をあけ直した。このサビの発生は, 黄銅板の存在によっ て塗装不十分な䇢所の腐食損傷が加速・増大したためと 推定される。

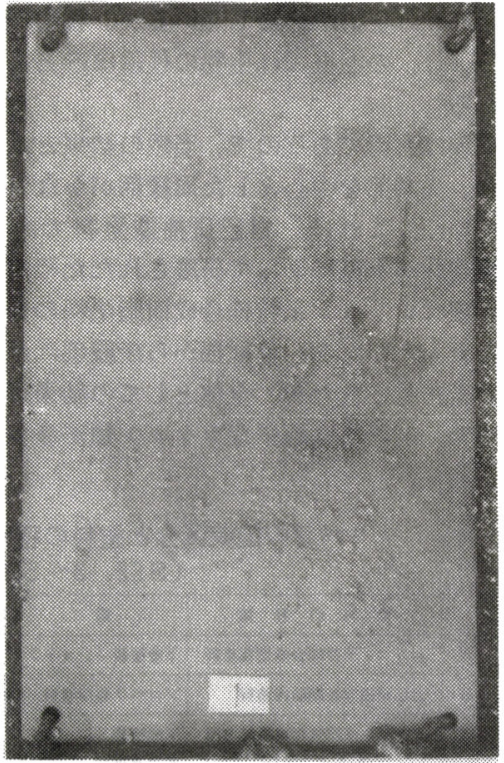

図 3 非防食黄銅浸漬板の表面状況

(S62.3 S62.9)

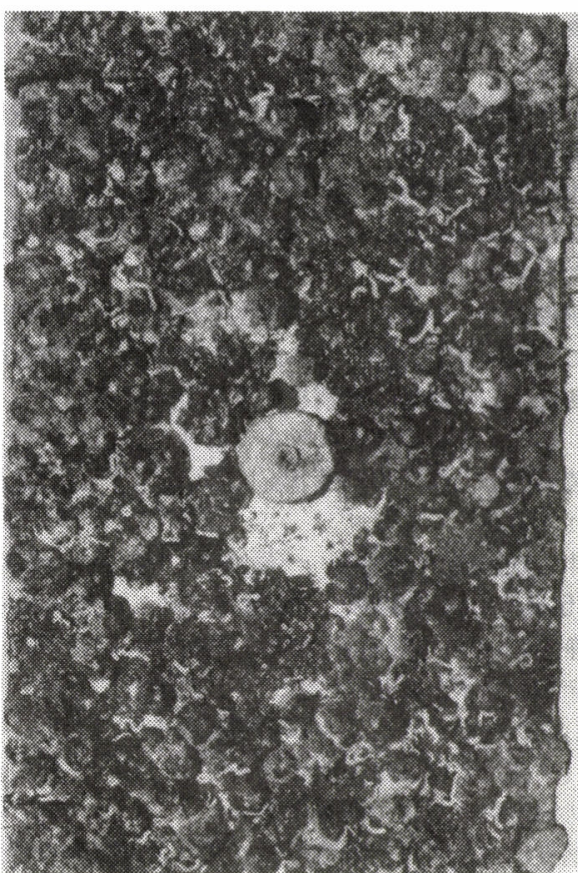

図 4 防食黄銅浸漬板の生物付着状況 （中央の円形状の物は亜鉛陽極， S62.3 S 62.9)

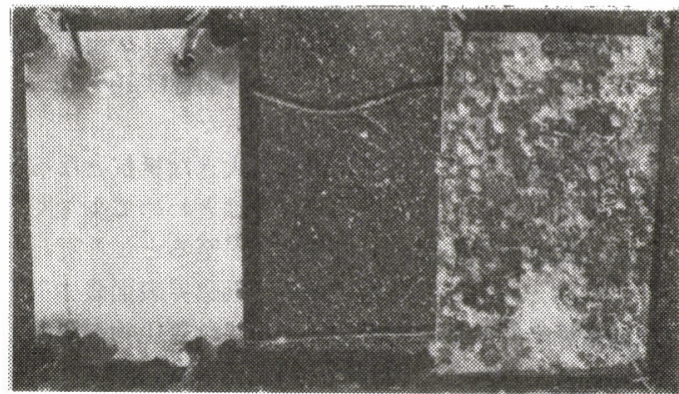

軟鋼板 (塗装)（Ａ）黄銅板（無塗装）

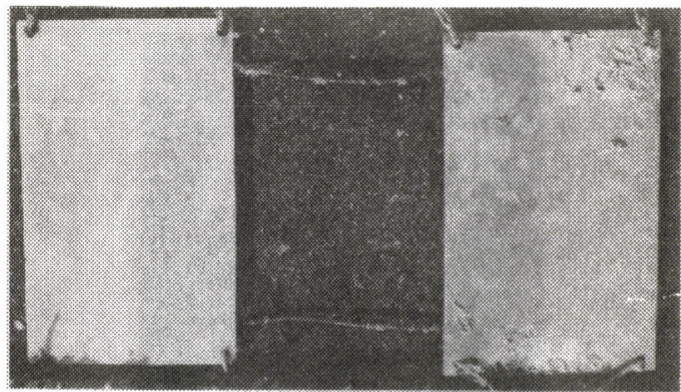

軟鋼板（塗装）（ B ） 黄銅板 (塗装

図 5 軟鋼-黄銅組合世浸漬板の污損状況

(S62.3 S62.11) 
以後もサビは少しずつ拡がっていったが, 試験板の脱 落は免れた。

この軟鋼板表面の塗膜はいわゆる自己研掃型であり, 有機錫化合物を含むポリマーが加水分解を起こし, 防污 剤が放出され，同時に唫膜自体も研磨される性質のもの である。したがって，全浸漬期間中を通して海中生物は 観察されず，付着物はスライムのみであった。

黄銅板については, サビの発生した塗装不十分箇所を 通して，軟鋼試験板との間に海中を経由した流電回路が 形成され, この結果, 軟鋼板によって防食されることに なる. 結局, 図 4 の防食試験板の場合と類似の状態とな り，黄銅板上での生物付着状況についても同様の結果が 得られている。

\section{4 軟鋼板（塗装）－黄銅板（塗装）の結果}

（図 5 B）軟鋼板, 黄銅板ともに, 表面はきわめ て清浄であった．軟鋼板上では，取付け孔近傍で腐食に よるサビがわずかに観察されたが，浸漬期間中ほとんど 進行しなかった．スライムは浸漬後徐々に増加し，6ケ 月後（ 9 月）にはほほ全面を覆っていたが, 生物の付着 は, 防污塗料の効果で皆無であった。

黄銅板については, 無毒性のシリコン系塗料を塗装し てあるためか，浸漬後 1 ケ月目から微細な海中生物の付 着が見られ始めた。 3 ケ月目（6月）になり水温が $15^{\circ} \mathrm{C}$ 以上になると, フサコケムシや他のコケムシ類が成長し てきた. 6 月〜 8 月にかけては主としてフサコケムシ， 8 月以降は主としてカンザシゴカイ類やフジツボ類が見 られた。しかし，板全体に対する付着割合は10２0\%の 範囲で推移し，増加することはなかった。

この黄銅板上では，水流に対して大きな抵抗となる殸 の高い生物（フジッボなど）の付着はきわめて少なく， しかも，塗膜表面にそれらの離脱跡が至るところ見られ た。これは, 本塗装の特徵である “低臨界表面張力”2) のため水流や何らかの物理力によって付着生物が脱落し たものと考えられる.図6にその拡大写真を示す。

なお，実際に塗膜表面に付着していたフジッボを手で 押したり，試験板全体に軽い衝撃を与えると容易に剶離

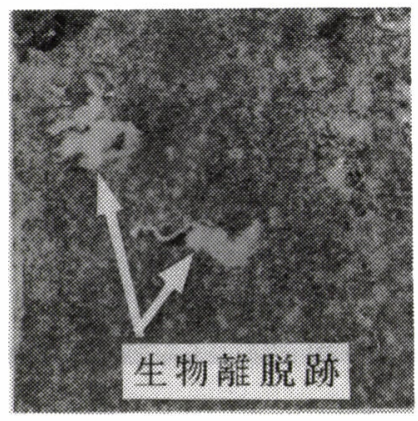

図 6 特殊合成樹脂塗装板上での付着 生物離脱跡
することから，実船の塗装プロペラに拈いても，回転中 の水の抵抗により付着生物が容易に離脱する可能性が大 さいと予測される。

さらに, 本試験板の塗膜状態は, 全試験期間を通して きわめて良好であったことから考えると，本塗装の船舶 や海洋構造物への適用は将来期待できるのではないかと 思われる。

\section{3. 実船実験}

3.1 プロペラ塗装実験昭和 62 年 3 月から 2 年間に渡って，学校練習船“弓削丸”によるプロペラ塗 装実験を行った．塗装作業やプロペラ表面の観察は 3 月 と9月の入渠時を利用した. 図 1 中にプロペラの要目を 示す.

まず，塗装の有無や塗料の違いがプロペラ污損状況に 及ぼす影響を調査するために, 最初の 1 年間は, 現在市 販されているプロペラ専用の自己研掃型防污塗料と筆者 らが着目しているシリコン系特殊合成樹脂塗料（普通夕 イプとデラックスタイプ）を塗布した実験を行った．

プロペラは 4 枚羽根であるので, 任意の羽根から時計 方向に $\mathrm{A}, \mathrm{B}, \mathrm{C}, \mathrm{D}$ 符号をつけ，キャップは $\mathrm{E} と し$ た. $\mathrm{A} \sim \mathrm{E}$ の塗装の要領は表 2 の通りである. 下地処理 として、すべてディスクサンダーによる研磨を行った 後, 無塗装の羽根 D以外はショッププライマーを塗布し た。

昭和 62 年 3 月から 9 月までの 6 ケ月間のプロペラ污損 状況の写真を図 7 に, そのスケッチを図 8 に示す.

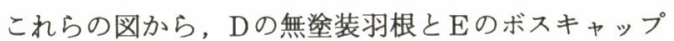
にはびっしりと生物が付着しているが, 各塗料を塗布し た A，B，C，の羽根では生物の付着はほとんどないこ とが分かる。

$\mathrm{B}$ 塗膜は有毒であるので, 当然の結果と考兄られる が，ただ，先端部を中心とした周縁部がかなりの範囲て 剝離していた。これは，自己研掃型塗料であるがゆえ に，塗膜自体が水流によって研磨されたためである。

$\mathrm{A}$ の羽根はシリコン系特殊合成樹脂塗料の普通タイプ を狳装したものである. 前縁部から後縁部にかけて塗膜 の剥離が若干見られたが, 全体としての結果はかなり良 好であった．表面には扁平なコケムシ類が多少付着して

表 2 プロペラの塗装区分と塗料の種類 (S62. 3 S63. 3)

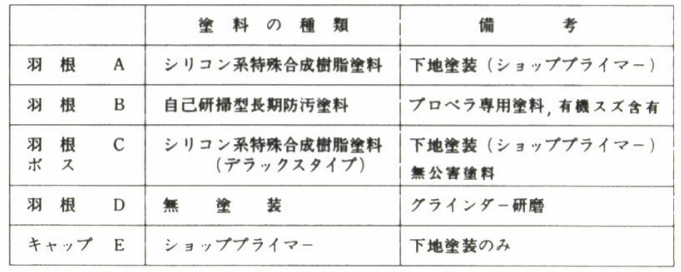




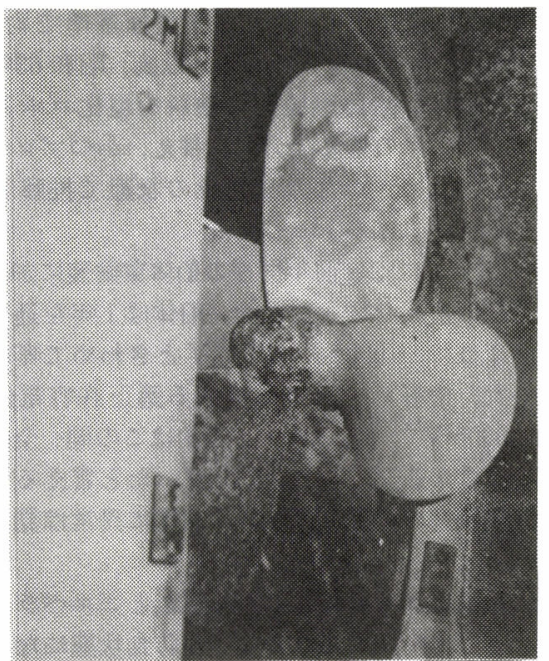

右上：(B)自己研掃型塗料（トリブチルスズ含有） 右下：(C)シリコン系特殊合成樹脂塗料（無害） 左下：(D)無 塗 装

図 7 プロペラ塗装の実験結果 (S62.3〜S62.9)

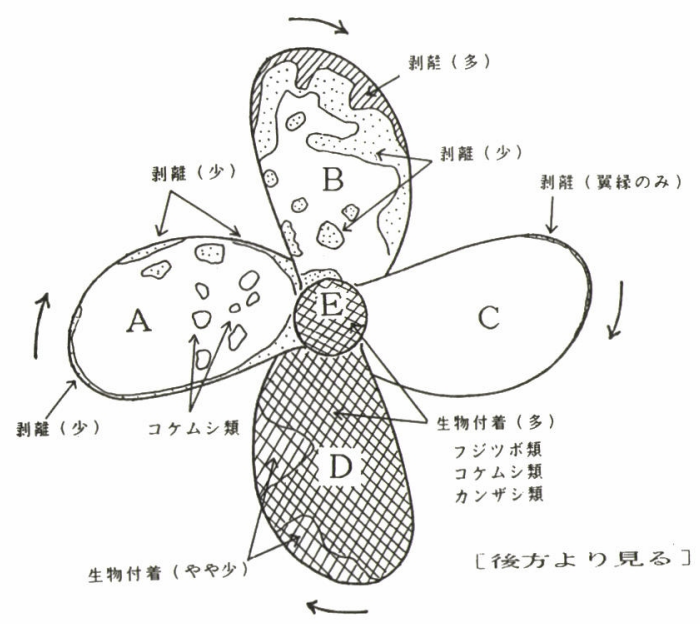

図 8 プロペラ污損模様

(S62. 3〜62.90結果)

いたが,フジッボ類は全くなかった。

$\mathrm{C}$ の羽根はBの塗料の付着力を一層高めたデラックス タイプを狳装したものである. 前縁, 後縁, 及び羽根先 端にごくわずかな剝離が見られたが，泀とんど問題にな らないよらな軽微なものであった。 また，生物の付着も 皆無であり，図 5 （B）の基礎浸漬実験での結果に比べ てはるかに優れた結果が得られた．プロペラの回転とい ら動的な条件下に拈いては，塗膜の物理的作用による効

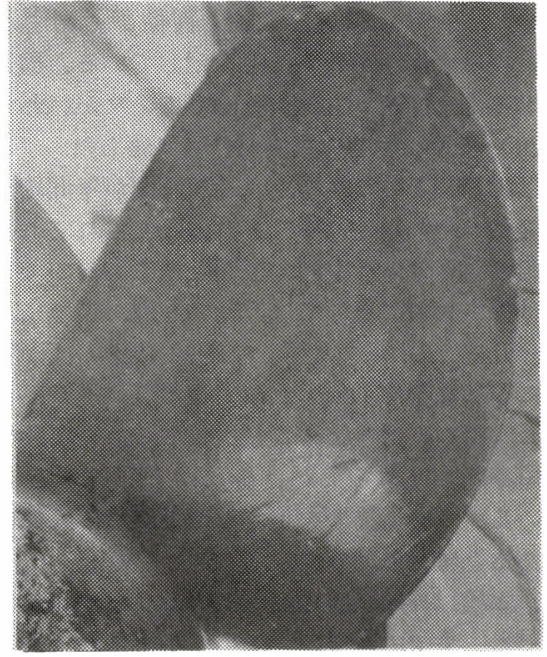

(a)半年後の結果（S63.3～S63.9）

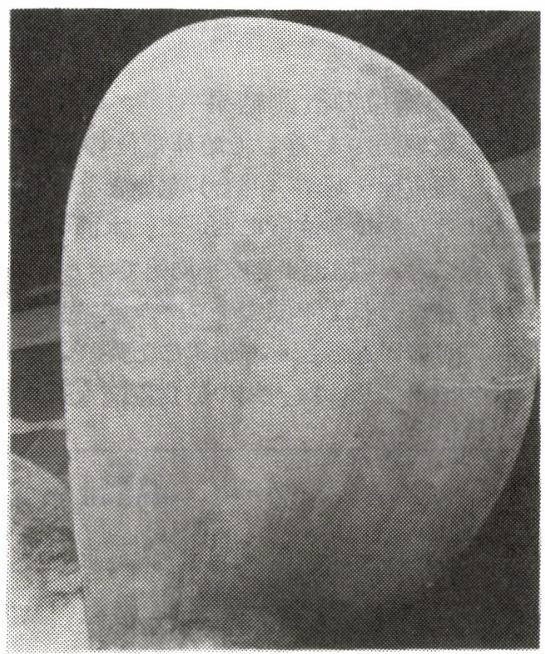

(b)一年後の結果 $(\mathrm{S} 63.3 \sim \mathrm{H} 1.3)$

図 9 塗装プロペラ翼面

果が大きいことを実証している．さらに6ケ月経過した 時点での観察においても, 表面の污損状況にはほとんど 変化が見られなかった。

な拈, 羽根先端の周速度は, プロペラ直径と回転数か ら算出して, 通常約 $30 \mathrm{~m} / \mathrm{sec}$ 程度であった.

以上の結果から分かるように，Cの羽根が最高の表面 状態を示していたので, 本シリコン系塗料をプロペラ全 面に塗った実船実験を, 昭和63年 3 月から平成元年 3 月 までの 1 年間実施した。

図 9 は半年後と 1 年後の入渠時に撮影した羽根表面の 写真である．期待していた通り，全翼とも圧力面・背面 を問わず污損はほとんどなく，塗膜はきわめて清净な状 態を維持していた。ところどころにプロペラ回転中に脱 落したものと思われる生物の離脱跡が見られた。翼縁に 
沿った鉣膜の剥離も前回の実験と同様ごくわずかであ り，本塗料の密着性が高いことを示している．周速度の 小さいボス部には海中生物が付着していたが，わずかな 押力（200～600gf 程度）で容易に滑り落ちた.

本船は練習船といら性格上, 運航時間が年間約 500 時 間と少なく，それ以外は停泊を余儀なくされており，ま た，本船の紫留地は瀬戸内の温暖な地にあるので，海中 生物の付着・繁殖にとっては非常に有利な環境にあるも のと思われる。しかし，プロペラ污損防止の面から言兄 ば，逆に不利な条件下に怙かれているが，それにもかか わらず，実験結果はきわめて優秀であった．実験は 1 年 といら短期間ではあったが，少なくとも，現在本船が 行っているプロペラ洗净を主とした半年毎の入渠は省略 可能であると考えられる.

なお，本校以外飞，広島商船高専及び大島商船高専の 練習船でも，すでに同様の実験結果が得られている.

今後の問題は塗膜の耐久性にあるが，現在，運航密度 がきわめて高く，かつプロペラ負荷の大きい民間船を利 用して実験を続けている。

\section{1 .1 船体電位の計測結果 プロペラ無㭡装} 及び塗装の実験期間中を通して船体電位の計測を行っ た. 海水塩化銀電極を基準（照合）電極として使用し， 因 1 に示すような船体各位置において，水面下 $1.5 \mathrm{~m}$ の 所に沈めて行った. 図10はその平均值で示してある.

昭和 61 年 3 月からの 1 年間のプロペラ無塗装時には, 船体電位は月日の経過とともに次第に上昇（貴方向に移 動）し，昭和62年 3 月には，鋼の防食電位（海水塩化銀
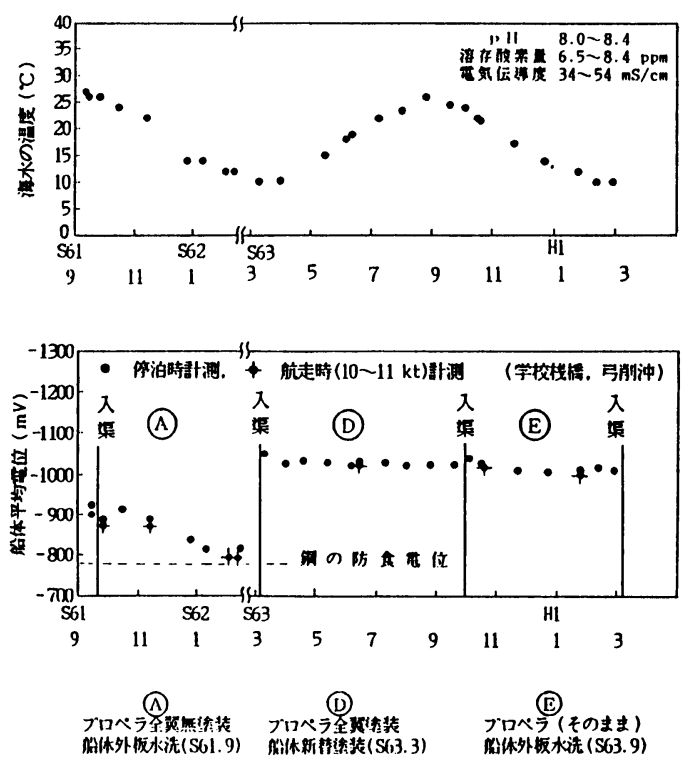

因 10 船体電位の変化 （海水塩化銀電極基準）
電極基準で約 $-780 \mathrm{mV}$, 飽和甘承電極基準で約 -770 $\mathrm{mV}^{9) \sim 12)}$ 近くまで到達している，以後，昭和 63年 3 月 までの 1 年間は, 船体塗装用の洤料を塩化ゴム系から タールエポキシ系の重塗装方式に替光，かつプロペラも 部分垐装したため，かなり卑電位の状態で推移してい た.

昭和 63年 3 月には，前年同様の船体重塗装に加え，プ ロペラ全翼の塗装を行ったため, 船体は 1 年を通して, 図に示すようにー1000〜 - 1050mV ときわめて卑な電位 で経過した. 塗料メーカの推奖する適正許容電位は一 $800 \sim-1000 \mathrm{mV}^{13)}$ であるので, 本船はこの間, 全体的に 見れば過防食が懸念される状態であったと言えるが，入 渠時の目視観察の結果では㓌膜の状態に異常は見られな かった.

今回, 重塗装系塗料による船体塗装とプロペラ全翼の 塗装といら二重の効果でこのような防食状態になったも のと考えられるが, 後者のみによる影響がどの程度で あったかは，本実験では不明である，目下，船体塗装を 同一にして,プロペラ無塗装状態での実験を行っている が，その状況から推察すれば, プロペラ塗装よりも船体 重塗装の影響の方が大きいようである.

な扔，図中には航走時の結果も記入してあるが，停泊 時との差は $10 \mathrm{mV}$ 程度であった。

\section{1 .2 儀牲陽極の消耗度本船では，儀牲陽} 極として亜鉛板を船体外板部及び舵部に計 48 枚（B-4 サイズ）設置しており，每年 3 月の入渠時に全数取り替 えているが, その時, 使用済みの亜鉛板について消耗重 量の計測を行った。

図11は，船体長さ方向各位置での儀牲陽極の消耗率 （S63.6〜 H1.3）を示す. この消耗率はP (左舷) 及び $\mathrm{S}$ (右舵) の平均をとり, 重量\%で表わしてある. バウ スラスター・トンネル内が $14 \%$ と最む大きく, 次に, ラ ダープレートの約 $8 \%$ ，それ以外は殆ど $6 \%$ 以下で あった。 バウスラスターの羽根にもシリコン系特殊合成 樹脂塗料を䇦布すれば，さらに消耗率が低下するものと 思われる. 前項の船体電位の計湘結果及び本項の檥牲陽 極の消耗度から考えて，亜鉛板の数が過㮃と思われるの

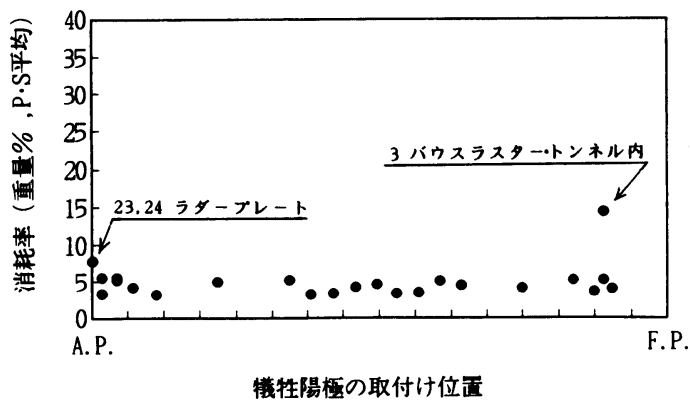

因 11 船体各位置での儀牲陽極 （亜鉛板）の消耗率（63．3〜 H1．3） 
で, 現在, 個数の削減や取り替え期間の延長について検 討を開始している.

\section{1 .3 船体・軸系の電位差及び軸電流電} 気防食によって, 船体が過度の低電圧にさらされると， 船体とプロペラ間の電位差が大きくなり，これらとプロ ペラ軸, 船尾管とで流電回路を形成し, 軸スリーブが陽 極となって腐食を生じることがある。つまり,図 12 に示

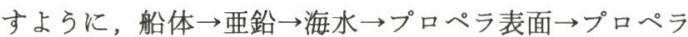
軸 $\rightarrow$ リーブ表面 $\rightarrow$ 船尾管内海水 $\rightarrow$ 船尾管 $\rightarrow$ 船体の経路 で電流が流れる。

な拉，停泊中（プロペラ軸が静止中）は，プロペラを 含む軸系と船体は軸受けを介して電気的導通がなされる ので, この間の抵抗値は 0 に近くなり, 電位差は消隇す る.

この軸スリーブの腐食防止対策の 1 つに, プロペラ軸 と船体とを直接接続する方法（軸アース装置）がある. この方法とプロペラ堆装 (絶縁) とを併用すれば, プロ ペラそのものの污損防止のみならず，軸スリーブの防食 効果を一段と高めることになる。また，船尾回りに多数 配置してある亜鉛板も大幅に削減できることになる。

表 3 は, “弓削丸”の船体・軸系電位の計測結果であ る。軸アースをしない場合の船体と軸系間の電位差は, 230〜270mVであるが，軸アースを設置した場合は0 $\mathrm{mV}$ とって扣り，本装置の効果が顕著に現れている。

3.1.4 プロペラ塗装が機関性能に及ぼす影響

図 13 は,プロペラ塗装時と無塗装時（夏季の污損 時)の機関性能の比較を行ったものである．常用時の370

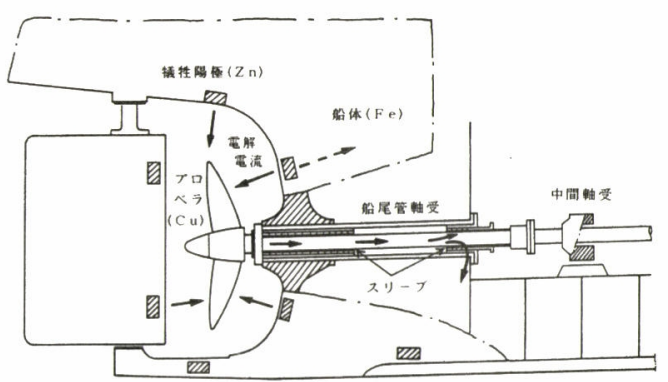

困 12 軸電流予想回路

(プロペラ軸回転中，軸アース無し）

表 3 船体・軸系電位の計測結果

（海水塩化銀電極基準，単位： $\mathrm{mV}, \mathrm{A}$ )

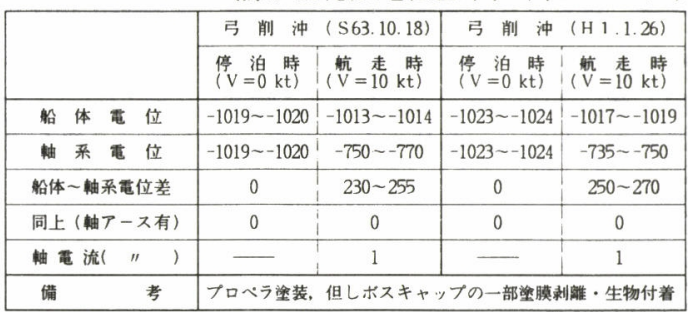

R.P.M. 前後の軸回転数に扔いて, 塗装時の方が無塗装時 に比べて, 然料消費量で約 $6 \%$ 減，スラストで約 $10 \%$ 減 となって抒り, プロペラ塗装による推進性能面での効果 が認められた。

3.2 FRPボートの船体塗装実験最近の海 洋レジャーの発展に伴って, FRP製ボートの利用が急速 に増加してきたが，このような船の船底にも有害な自己 研掃型塗料が塗られている.

そこで,プロペラ塗装実験で使用した無害のシリコン 系特殊合成樹脂塗料が, FRPボートの船体にも適用でき るかどらかを検討するため，海中生物の成長時期に当る

5 月末から 7 月末にかけて塗装実験を行った。

使用したボートは, 広島大学付属臨海実験所所属の海 中生物調査用のものである。図 14 の写真で分かるよう に，船体の污損は殆どなく，清浄な表面を維持してい た. 本実験は 3 ケといら短期間であったので,ささらに 長期の実験・観察が必要である.
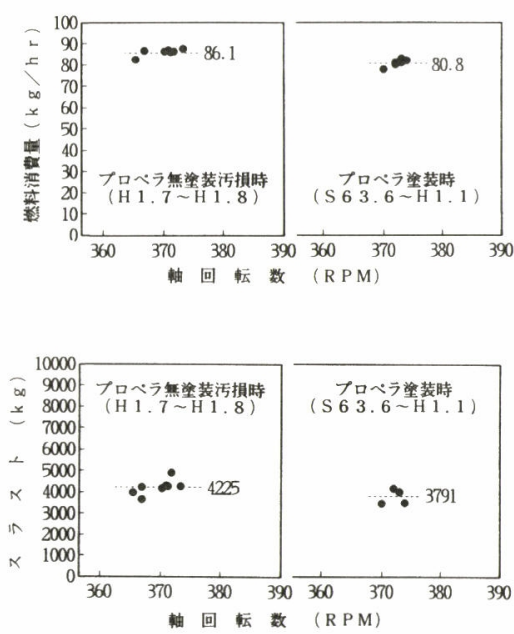

図 13 プロペラ塗装時の無塗装時の 機関性能の比較

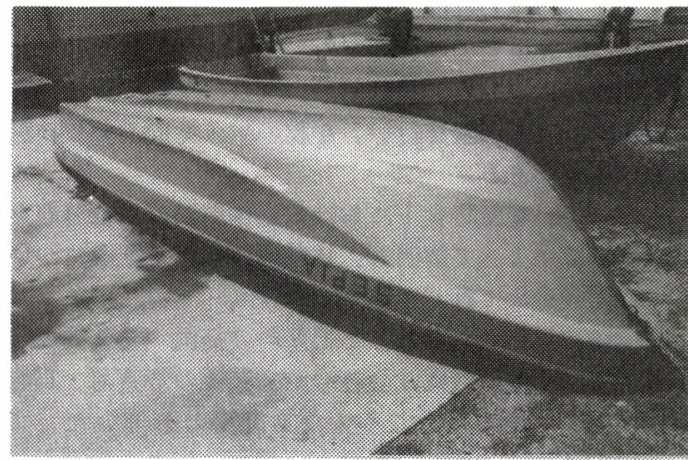

図 14 無公害塗料を淕布したFRPボートの污損状況 （H元年 5 月末～H元年 7 月末） 


\section{4.まとめ}

船体とプロペラ間に生ずる異種金属電池の形成を抑制 し，儀牲陽極個数の削減を計るため，また，プロペラ表 面の生物付着による污損を防止するため，筆者らは，数 年前よりプロペラ塗装実験を行ってきた。

使用した塗料は，陸上関係の海水管系統などの特殊用 途として開発されているシリコン系特殊合成樹脂塗料で ある。

本鯐料は，無公害といら利点があり，かつ従来の塗料 とは違って低臨界表面張力といら塗膜性質を有している ので，水流などの物理力によって付着生物が容易に離脱 し，防污効果を発揮するといらニニークな染料である.

試験板による浸漬実験と本校練習船“弓削丸”による 実船実験を通して，次のようなことが判明した．

(1) 無塗装・防食黄銅板表面には多数の海中生物が付 着するが，無塗装・非防食黄銅板にはスライムのみで， 生物の付着は皆無であった．海中への銅イオンの溶出の 有無が生物の付着・成長に影響を及ぼしたものと考えら れる。

（2） 1 年間の実船実験の結果, シリコン系特殊合成樹 脂塗料を塗布したプロペラ表面は, 生物の付着も塗膜の 剥離も殆ど見られず，きわめて清浄な状態を維持してい た.

（3）船体重塗装にプロペラ塗装を併用することによっ て，船体電位は大幅に低下（卑方向に移行）した。過防 食による塗膜への影響が心配されたが，入渠時の目視観 察では異常は認められなかった。

（4）今回の実験により，儀牲陽極である重鉛板の消耗 度が減少し, 亜鉛板個数の大幅な削減が可能となった。

(5) プロペラ塗装の結果，主機の燃料消費量は約 $6 \%$ 隇少し, 省エネ効果が得られた。

（6）本実験で使用した無公害のシリコン系特殊合成樹 脂垐料は, 生物付着防止の面, 推進効率向上の面及び海 水污染防止の面から，プロペラの防污用として将来有望 であるように思われる。

今後は，本練習船のような停泊期間の長い船だけでな く，使用頻度が比較的高い船や，プロペラ回転数の大き い船についても実験を行い，筀膜の耐久性について検討 するつもりである.

また一方，電気防食下に拈ける船体周囲の電位分布を 実験と計算によって解明し，燨牲陽極の適正配置につい ても検討を進めて行く予定である。

本実験の遂行にあたり，一部登料の提供・筀装要領の 指導等で，中国塗料株式会社今治営業所の畑賀忍・馬場 国雄・勝矢文雄の各氏に多大なる御協力を仰いだ。ま た, FRPボートの塗装実験に括いては, 広島大学理学部 向島臨海実験所の片山平三郎教授に快く実験船を提供し ていただいた．さらに，船体電位の計測や基礎浸漬実験
の準備等で，弓削丸乗組員の方々の手を煩わせた．以上 の諸氏に，紙面をかりて厚く御礼を申し上げます.

\section{文献}

1）例之ば, 日本舶用機関学会：船舶電気・電子工学便覧, 海文 堂, (1981).

2）中国登料(㑣，バイオクリン資料一般的には，工業技術会： 「無公害生物付着防止対策の最新技術」講習会テキスト， (1989).

3）松下・小川：プロペラ塗装に関する実船実験（1），全船協 技報，第 8 号，(1988）

4）松下・小川：プロペラ塗装に関する実船実堬（2）, 全船劦 技報，第 9 号，(1988)，

5）小川・松下：プロペラ豚装に関する実船実的（3）, 全船協 技報，第 10 号，(1989)。

6) 宮嶋: 生物付着と影数, 海難と審判, 79号, (1988).

7）中尾：船舶塑料について（その 7)，船の科学，39-3， (1986).

8）三原他 3 名：プロペラ電気防食の海洋生物付着に及活す影 整, 舶機誌, 20-4 (1985).

9）日本防食工業(湖：人工海水塩化銀照合電梗「取扱説明書」

10）宮嶋：電気防食技術，(表 3 ），舶機誌，16-9，(1981)

11）演田：防錆・防食の事例（5），船の科学，40-3，(1987）。

12）玉利：電気防食の原理と応用, 日本造粘学会誌, 第627号, (1981).

13）中尾：船舶用登料について (その 24)，船の科学，40-8，

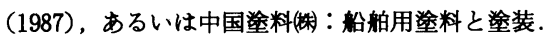

\section{[質 疑 応 答 $]$}

質問者：大島商船高専 三原伊文

[質問］

シリコン系特殊合成樹脂塗料を塗布した浸漬羽根に付 着した生物は，潮流や波による上下運動ぐらいの物理力 でも離脱するのですか.

[回答]

場合によります，本校栈橋での潮流は最高 2 ノットで す、試験板による基礎実験によりますと,この程度です ベり落ちる生物もあります．船の航走波を受けて脱落し たり，観察のために引き上げ，下げ降ろしをする途中で 豩離するフジッボやホヤなども見られます。

試験板に付着したフジツボを横に押してみますと，大 きさにもよりますが，大体200〜600 $\mathrm{gr}$ 程度の力ですべり ます，プロペラの場合，羽根にはほとんど付着生物は見 られませんでしたが, 羽根根元やボス部の周速度のきわ めて遅い箇所には，コヶムシなど扁平な生物が残ってい ました．しかし，これもわずかな押力ですべり落ちま す. 